\title{
The Perception of School Climate in two Secondary Schools during the Implementation of a Peer Support Program
}

\section{Soledad Andrés Gómez ${ }^{1}$ \& Sandrine Gaymard ${ }^{2}$}

${ }^{1}$ Departamento de Ciencias de la Educación, Universidad de Alcalá, Alcalá de Henares, Madrid. LPPL, Universidad de Angers, Francia.

2 Laboratoire de Psychologie des Pays de la Loire (LPPL), EA 4638, Universidad de Angers, Angers, France

Spain / France

Correspondence: Soledad Andrés Gómez. Departamento de Ciencias de la Educación, c/ San Cirilo, s/n. 28801Alcalá de Henares, Madrid, Spain. E-mail: soledad.andres@uah.es

(C) Education and Psychology I+D+i and Editorial EOS (Spain) 


\section{Abstract}

Introduction. The problem of school violence has been studied in the last decades from different perspectives, especially focused on bullying conflicts. Whole school approaches have been recommended by many experts in the field. The aim of the present study is to assess climate changes in two secondary schools that implement a peer support program, and to understand the level of perceived satisfaction.

Method. Pre-post study with experimental and control group. Participants were 778 pupils (3 phases) plus 65 teachers at the experimental school; 462 pupils and 29 teachers at the control school. The tools used were questionnaires, focus groups and intensive interviews.

Results. All participants believe that the peer support program is useful for improving the perception of safety at school, while the responses of the control school students indicate a general increase in the frequency of conflicts.

Discussion y conclusion. Results show the complexity of controlling all the variables linked to changes of context. However, as proposed previously by other authors, objective measures need to be used in assessing school climate, in addition to perceptions shown on self-reports, in order to accurately determine the impact of peer support programs.

Keywords: school climate, assessment, peer support program, conflicts, bullying 


\section{La percepción del clima escolar en dos institutos de Educación Secundaria durante la puesta en marcha de un Programa de Ayuda entre Iguales}

\section{Resumen}

Introducción. El problema de la violencia escolar se viene estudiando desde distintas perspectivas teóricas en las últimas décadas, centrándose de manera especial en el maltrato entre iguales por abuso de poder o bullying. Numerosos expertos han recomendado su tratamiento desde un enfoque global de centro. El trabajo que aquí se presenta consiste en la evaluación de los cambios en el clima en dos centros de secundaria durante la inserción y desarrollo de un programa de ayuda entre iguales, con objeto de conocer la satisfacción percibida.

Método. Estudio pre-post con un grupo experimental y otro de control. Los participantes fueron 778 alumnos/as ( 3 fases) y 65 profesores del centro experimental; 462 y 29 respectivamente del centro control. Los instrumentos utilizados han sido cuestionarios, grupos de discusión y entrevistas en profundidad.

Resultados. Todos los participantes consideran que el programa de ayuda entre iguales es útil para la mejora de la percepción de la seguridad en el centro, si bien las respuestas de los alumnos del centro experimental indican un aumento general de la frecuencia de los conflictos

Discusión y conclusión. Los resultados muestran la complejidad para controlar todas las variables vinculadas a los cambios en el contexto. No obstante, de acuerdo con las propuestas hechas previamente por otros autores es necesario el empleo de medidas objetivas en la evaluación del clima escolar, más allá de las percepciones que muestran los autoinformes, para determinar con precisión el impacto de los programas ayuda entre iguales.

Palabras Clave: clima escolar, evaluación, programa de ayuda entre iguales, conflictos, bullying 


\section{Introduction}

\section{Approaching the problem}

The study of interpersonal relationships in schools is probably one of the most complex fields of study in educational psychology. Although research interest has existed in the social and educational field since the middle of the last century (Amidon \& Hough, 1967, Flanders, 1964; Hargreaves, 1978); investigation has greatly increased in recent decades in European countries. The strong influence of Olweus' studies on bullying in Norway in the early seventies is observed through the wide dissemination of its results throughout the continent, in the eighties and nineties, marking a renewed interest by the researchers in the field (see Smith, Morita, Junger-Tas, Olweus, Catalano \& Slee, 1999). At the same time, intervention projects appeared to deal with the problem, emphasizing the impetus of experiments in Great Britain that promoted specific programs and materials from different European networks and projects (Cowie, Naylor, Talamelli, Chauhan \& Smith, 2002; Cowie \& Jennifer, 2007; Cowie, Jennifer, Chankova, Poshtova, Deklerck, Deboutte, Ertesvåg, Samuelsen, O’Moore, Minton, Ortega \& Sanchez, 2007; Naylor \& Cowie, 1999; Salmivalli, Kärnä \& Poskiparta, 2010). While most programs started in the eighties as anti-bullying programs, today they have evolved into what is known as a whole school approach, which focuses on global improvement of the institutional climate. Researchers have recently analyzed some of these wide-ranging programs (Thompson \& Smith, 2011), and fourteen pre-post test studies that look at the effectiveness of interventions have been described (Smith, Pepler \& Rigby, 2004). It is also important to mention that there is an open discussion in the field about the limitations of the analysis of programs and design features (Smith, Salmivalli \& Cowie, 2012; Spiel, Salmivalli \& Smith, 2011; Ttofi \& Farrington, 2011)

In the case of Spain, accelerated social changes have been experienced in the last decades, and schools have been directly affected by them. As the first results of the TALIS OECD report (2009) show, as well as the Spanish national school violence study previously mentioned (Defensor del Pueblo-UNICEF, 2007), teachers' perceptions of the school climate are negative for a high percentage of the staff.

Changes in the traditional concept of authority, and consequently, the difficulties of building new relationships in current teaching and learning contexts, are some of the reasons underlying the problems. Thus, school conflicts and violence are one of the main concerns of 
Spanish administrations, researchers and practitioners. A wide variety of prevention programs, some of them Spanish versions of British peer support, have been implemented all around the country. But these innovative experiences at schools have hardly been evaluated with scientific rigor. The main results of the evaluation of the Peer Helper program implemented in a Madrid secondary school are presented here.

\section{The European perspective: from the study of bullying to school violence}

Following the detailed compilation work of European studies and interventions done by Smith (2003) and Smith, Pepler and Rigby (2004), the general results show equivalent data: a low incidence of the case of school violence, while there is a growing preoccupation with the study of bullying. Nevertheless, the wide variety of evaluation instruments makes rigorous comparison of the final results difficult. This has to do with the evaluation data and the type of intervention. Related to the school climate and the effects of peer support systems, Cowie and Smith (2013) point out that there is little objective evidence to allow us to understand their effects and the perception of safety in any detail.

These reviews of research and practice in the field indicate that intervention began with a focus on school bullying and evolved into a systematic concern for the improvement of the school climate as a whole, often referred to as a Whole School Approach (WSA). Support for the effectiveness of a WSA comes from such collaborative programs as the Violence in Schools Training Action (VISTA Project) (Cowie, Jennifer, Chankova, Poshtova, Deklerck, Deboutte, Ertesvåg, Samuelsen, O’Moore, Minton, Ortega \& Sánchez, 2007), whose main objective is the promotion of non-violence in schools and positive relationships between all the members of the school community (see also Cowie \& Jennifer, 2008). Teacher and student training is also part of the systemic approach, based on good practice in educational administrations in several European countries.

In Spain, many studies focusing on violence and bullying, and promoted by the central state and regional administrations, have been performed since the pioneering studies of Fernández and Quevedo (1992) at the beginning of the nineties. Today, national law (L.O.E., 2006) and the related regional level laws have developed an interest in the topic, as shown by two national studies carried out by the National Ombudsman and UNICEF (2000/2007). Andrés' study (2009) collected the opinions of 498 pupils, 65 teachers and 226 families con- 
cerning the school climate in a secondary school. The findings show the negative view of the teaching staff concerning interpersonal relations, the frequency of conflicts and the different solution strategies on the part of pupils and families. In the same way, teachers and families have different perceptions of normative rules for living together. Gaymard, Andrés and Fernández (2002) had 259 pupils between the ages of 12 and 16 fill out a questionnaire to study school climate. The authors reveal that school conflict and especially verbal violence are ever present at this junior high school located in a "sensitive" area. It is usually the youngest children who are the victims of violence, but at the same time they appear to be the most unruly. As a consequence, this topic has been incorporated as one of the key subjects in teacher training as part of innovation processes, with special emphasis on the school psychology courses (Barrios, Andrés \& Granizo, 2011).

With regard to interventions, national, regional and local programs have spread all over the country (e.g., Atlántida, SAVE, for a full revision see Andrés, 2007) and share the same perspective: the prevention of conflicts and the systemic orientation of the interventions. On the negative side, we also observe very few evaluations (Del Barrio et al, 2011).

\section{Peer interactions in adolescence and Peer Support programs}

Psychological research on peer interactions finds its origin in the Piagetian and Vygotskyan complementary tradition. The different emphases in understanding the changes that appear in childhood on one hand thought to begin with the appearance of cognitive conflict (Piaget, 1932), on the other hand considering the role of social context for personal development (Vygotsky, 1978), set the basisfor the recent interest in the peer mediation process in the wide field of social sciences. Tudge and Rogoff (1995) point to the importance of language as the essential semiotic instrument in interpersonal communication, emphasizing its development for shared comprehension and meaning. In this sense, these authors understand that "[conflict] can very reasonably be considered as an opportunity to discuss a problem and coordinate a common activity to solve it" (p. 116). The questions asked at the start of implementing peer support systems were whether their structures were capable of improving student-student and student-teacher relationships, whether they could stop aggressions and/or bullying acts, whether they could prove useful for developing students' social skills, and whether they could influence school climate. 
As the research in the field has been moving forward, intervention programs have focused not only on individuals, but also on the group where abuses have occurred (Barrios, Andrés \& Granizo, 2011; Martín, Fernández, Andrés, del Barrio \& Echeita, 2003). As Salmivalli and other researchers have repeatedly shown (1998b, 1999; Salmivalli., Kaukiainen \& Voeten, 2005; Salmivalli, Kaukiainen, Voeten \& Sinisammal, 2004; Salmivalli, Lagerspetz, Björkqvist, Österman \& Kaukianen, 1996; Salmivalli \& Voeten, 2004), there are strong connections between behaviors and attitudes, group norms, moral ethos and cognitive interpretations of the relationships within the groups, which can in turn explain the group roles played by peers in bullying situations.

The importance of having a best friend as a protection factor, in the face of aggressive acts or social exclusion on the part of the peer group, has been pointed to in early studies in the field (Boulton, Trueman, Chau, Whitehand \& Amatya, 1999; Cowie \& Wallace, 2000). This implies that interventions that encourage students to develop friendships can be suitable tools for vulnerable young people. In bullying studies, an increasing number of researchers consider the bullying phenomena as a relationship problem (Salmivalli, 1999; 2010; Salmivalli, Kärnä \& Poskiparta, 2010); at the same time they present a number of results that reveal a small number of students determined to help victims. In Spain, the Ombudsman National Report on School Violence (Defensor del Pueblo-UNICEF, 2000-2007) showed a percentage of victims that do not report their suffering to anybody, and that friends are the persons who adolescents look to for support when they are in trouble, much more than teachers or families.

Introduced in Spain at the beginning of the century, peer support programs were adapted by Fernández (Fernández, Villaoslada \& Funes, 2002) from the first Anglo-Saxon models developed in the UK by Cowie and her research team (Cowie \& Sharp, 1996; Cowie $\&$ Wallace, 2000), and share the same theoretical orientation. Peer helpers are volunteer students chosen by their mates in classroom sessions, according to a pro-social profile. Directed by the teacher, the class group has previously discussed the kind of conflicts they find in school and classroom daily life, mainly between students, though teacher-student problems are also considered. So, this model of peer support is presented as a tool-students helping students - whenever emotional or relational needs are detected, and the peer helper figure is legitimated through democratic election by peers. 
Thus, peer helpers receive specific training in communication skills and other core social skills, from a problem-solving approach. After completing the training, they mediate in interpersonal conflicts, their interventions being regularly supervised in student helper group sessions by teachers in charge of the program. In short, the goal is to improve school climate and reduce bullying through the promotion of student participation in conflict resolution, in order to increase civic values through shared responsibility and through involvement in the affective climate of the school as a whole (Sharp \& Cowie, 1998).

Furthermore, in the everyday practice of peer supporters, student interventions follow principles of confidentiality, compromise, respect, solidarity, availability and justice, the general idea being respect for and protection of the needs and rights of persons as identified in the Universal Declaration of Human Rights.

\section{Evaluation of the Peer Support programs}

Prior assessments show that peer support programs are powerful instruments for experiencing and improving social skills through feelings. Nevertheless, because of the variety of assessment methods, it is difficult to make comparisons and, consequently, there are results that lead to conflicting conclusions about the factors that improve school climate. However, there is strong evidence that peer support improves the school climate, even though in the early stages of implementation, results can show an increase in conflicts (Del Barrio, Barrios, Granizo, Van der Meulen, Andrés \& Gutiérrez, 2011; Cowie, 1998; Cowie, Naylor, Tallamelli, Chauhan \& Smith, 2002; Cowie \& Olafsson, 2000; Cowie \& Wallace, 2000; Houlston, Smith \& Jessel, 2009; Mental Health Foundation, 2002; Naylor \& Cowie, 1999; Naylor, Cowie \& Del Rey, 2001; Ortega \& del Rey, 2001; Ortega, Del Rey \& Mora-Merchán, 2004; Smith, 2003; Smith, Pepler \& Rigby, 2004; Smith \& Watson, 2004). More precisely, in studies that have used control groups, results to date have not been homogeneous and have not revealed differences in evolution, in specific cases, between experimental and control schools (Svensson, 2003).

\section{Aim and hypotheses of the study}

The aim is to study the perception of school climate and perceived satisfaction after implementation of a peer support program. We put forward the following hypotheses: 
H1: The perception of conflicts will be different between the two schools

H2: There will be more reported cases of verbal aggressions.

H3: The program will be appreciated by students and teachers.

\section{Method}

\section{Participants}

In the experimental school, 778 pupils participated in the study. The average age of the group was 13.7 years $(\mathrm{SD}=1.9)$. A peer support program based on "peer education" and help between peers was implemented in this school. The model is widely extended in Anglo-Saxon culture (Cowie \& Sharp, 1996), having become an important intervention strategy for the improvement of school climate. In the control school, 462 pupils participated to the study. The average age of the group was 14.1 years $(\mathrm{SD}=1.1)$.

This study in 3 phases (pre-test, median and post-test) was carried out in two secondary schools acknowledged to be similar, both of them located in a suburban area on the outskirts of Madrid (Spain). More than 38\% of the population are recently-arrived immigrants, primarily from Latin American countries. See Table 1.

Table 1. Participants in the school climate study

\begin{tabular}{lcccc}
\hline PHASE & \multicolumn{2}{c}{ EXPERIMENTAL GROUP } & \multicolumn{2}{c}{ CONTROL GROUP } \\
\hline & Students & Teachers & Students & Teachers \\
\hline $1=$ Pre-test & 261 & 33 & 112 & 27 \\
\hline $2=$ Median & 280 & - & 180 & - \\
\hline $3=$ Post-test & 237 & 32 & 170 & 26
\end{tabular}

\section{Instrument: climate assessment}

The instruments used were school climate questionnaires (Andrés, 2009a; Gaymard, Andrés \& Fernández, 2002) for students (Cronbach's alpha=0.86) and teachers (Cronbach's alpha $=0.81$ ), including a wide range of questions from different categories according to climate factors. These factors allow assessment at the school level (macro perspective) or the class level (micro perspective) (see Table 2). 
Table 2. School climate factors questionnaire

\section{School climate factors}

\section{SOCIAL SYSTEM}

- Relations and interactions between students and self assessment

- Relations and interactions between teachers and self assessment

- Teacher/student and student/teacher relations and interactions

1. Conflict perceptions, types and frequency

2. Resolution strategies, rules and discipline

- Relations and interactions between teachers/students/school administration/other staff/families

- Relationships between families

TEACHER BEHAVIOR EXPECTATIONS AND STUDENT ACHIEVEMENT

PARTICIPATION, COMMUNICATION AND DECISION TAKING

SCHOOL AND SOCIAL SAFETY ENVIRONMENT

\section{Classroom climate factors}

\section{SOCIAL SYSTEM}

- Relations and interactions between students

1. Friendship and help behaviors.

2. Bullying and aggression

1. Teacher/student and student/teacher relations and interactions Conflict perceptions, types and frequency

2. Resolution strategies, rules and discipline

\section{TEACHER EXPECTATIONS AND CLASSROOM METHODOLOGY}

The student questionnaire has 33 questions: dichotomy multiple choice and Likert scale degree of agreement. The teachers' questionnaire is composed of 31 questions: dichotomy multiple choices and Likert scale degree of agreement. These questionnaires make it possible to compare pupils' and teachers' perception of the different types of conflicts and aggression and their frequency within the school and the classroom. Pupils are also questioned about their personal experience as a bully or a victim, and teachers about the way they 
intervene in conflicts and their anti-bullying strategies within the classroom. In this paper we will report only the differences observed between the experimental and the control group (Table 1 above).

\section{Procedure: Program assessment at the experimental school}

All the students and teachers of the experimental school were asked about the program implementation and its influence on school climate. On the other hand, peer supporters and other volunteer pupils - non supporters- as well as participating teachers took part in focus groups to evaluate the program implementation on two occasions (Andrés, 2009a; Andrés \& Martín, 2002). Finally, the effects of the program on participating pupils were also measured (Andrés, Barrios \& Martín, 2005; Andrés, Gaymard \& Martín, 2005). A semi-structured interview with the head teacher and the program coordinator was carried out with the objective of evaluating school climate changes.

\section{Design and data analysis}

Analysis of results was carried out using the statistical package SPSS 9.0. The statistics used were the means for the scale questions, for analysis of variance (ANOVA) and percentages for the dichotomous items (chi-Square). The level of significance is between $95.0 \%$ and 99.0\%, the risk level being between $0.05(p \leq .05)$ and $0.01(p \leq .01)$

\section{Results}

Changes in school climate from the pupil's and the teacher's perspective

\section{Frequency and types of aggression and conflicts from the pupil's perspective}

According to the information reported by pupils, there was a general increase in the frequency of conflicts in the experimental school, while they decreased in the control school (macro perspective). There were statistically significant differences in the averages $[F(2,76)$ $=5,92, p<.003$ ] between phase 1,2 and 3 intakes on a Likert scale of 1-5 at the school where the program was implemented. As Figure 1 shows, the control school took the opposite 
path, with mean differences $[\mathrm{F}(2,11)=3,81, \mathrm{p} \leq .02]$ between the first, second and third phases.

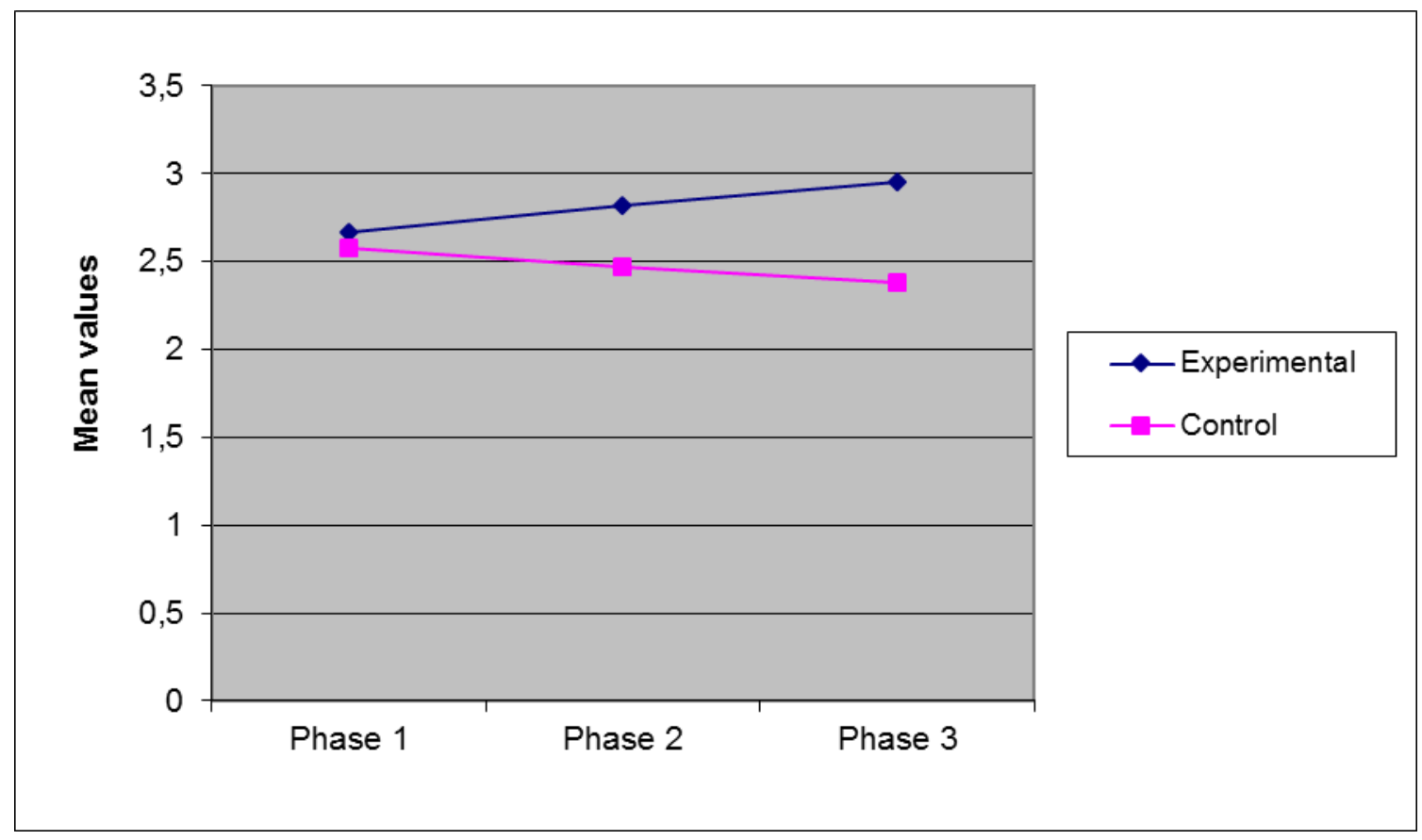

Figure 1: General frequency of conflicts at school level

Asked about the incidence of different types of conflicts at the classroom level (micro perspective), pupils chose between seven options. In both schools they pointed to high percentages of disruptive behavior (an average of 70\%) though differences $\left[X^{2}(1)=5.31, p \leq\right.$ .02] separate them in phase 3 where the control school gets higher percentages. Though student's lack of respect towards teachers is the second most frequent conflict in percentage in all phases, schools differ at each data intake when students answer about teacher's lack of respect towards students: with higher significant differences in phase $1\left[X^{2}(1)=14.32, p \leq\right.$ $.0001]$, in phase $2\left[X^{2}(1)=8.84, p \leq .003\right]$, and $3\left[X^{2}(1)=6.3, p \leq .01\right]$, respectively. Aggres sions between students, with equivalent percentages in phases 1 and 2 have greater predominance at the experimental school $\left[\chi^{2}(1)=6.94, p \leq .008\right]$, with differences disappearing in phase 3, though high percentages of conflict are maintained at both schools (see Figure 2) 


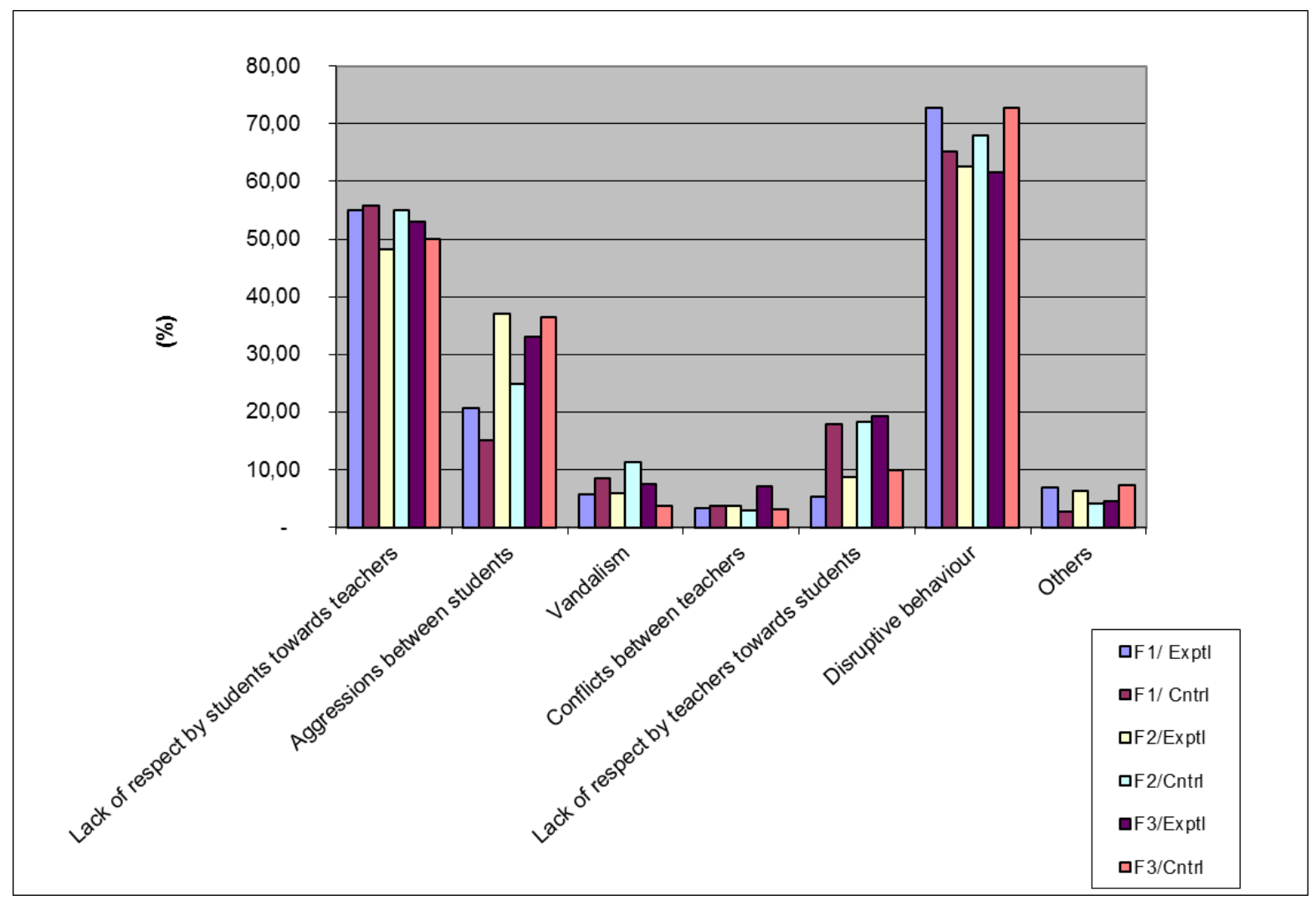

Figure 2. Types of conflicts in the classroom

Regarding aggressions between students at the school level, students chose from seven options. Results show higher percentages in verbal aggressions and significant differences in phase $1\left[X^{2}(1)=4.67, p \leq .03\right]$ and $3\left[X^{2}(1)=84.2, p \leq .001\right]$, where this conflict decreases in the control school and similar percentages are maintained in the experimental school. Physical aggressions is the second highest category that worries students, as it is also chosen by a high percentage, and shows differences in school evolution as follows: an average of $26.1 \%$ in phase 1 , starting to show percentage differences in the second data intake -lower in the control school than in the experimental school-, and finally becoming more significant in phase 3 $\left[X^{2}(1)=22.24, p \leq .0001\right]$.

Social exclusion is more noted by experimental students $\left[X^{2}(1)=11.25, p \leq .01\right]$, though percentages are equivalent in phase 2 and 3. Therefore, highly significant differences are found in the evolution between phases in the experimental school $\left[X^{2}(2)=16.83, p \leq\right.$ .0001]. Vandalism also shows differences between schools, with control percentages now higher than experimental percentages in phase $1\left[X^{2}(1)=6.86, p \leq .009\right]$; similar percentages in phase 2 , then separating again in phase $3\left[X^{2}(1)=9.75, p \leq .002\right]$. Finally, when asked 
about aggressions of less importance, student opinions differ between schools in the last two phases: starting from an equivalent initial situation, scores separates in phase $2\left[X^{2}(1)=6.3, p\right.$ $\leq .01]$ and in phase 3 with highly significant differences between them $\left[X^{2}(1)=16.8, p \leq\right.$ $.0001]$. See Figure 3.

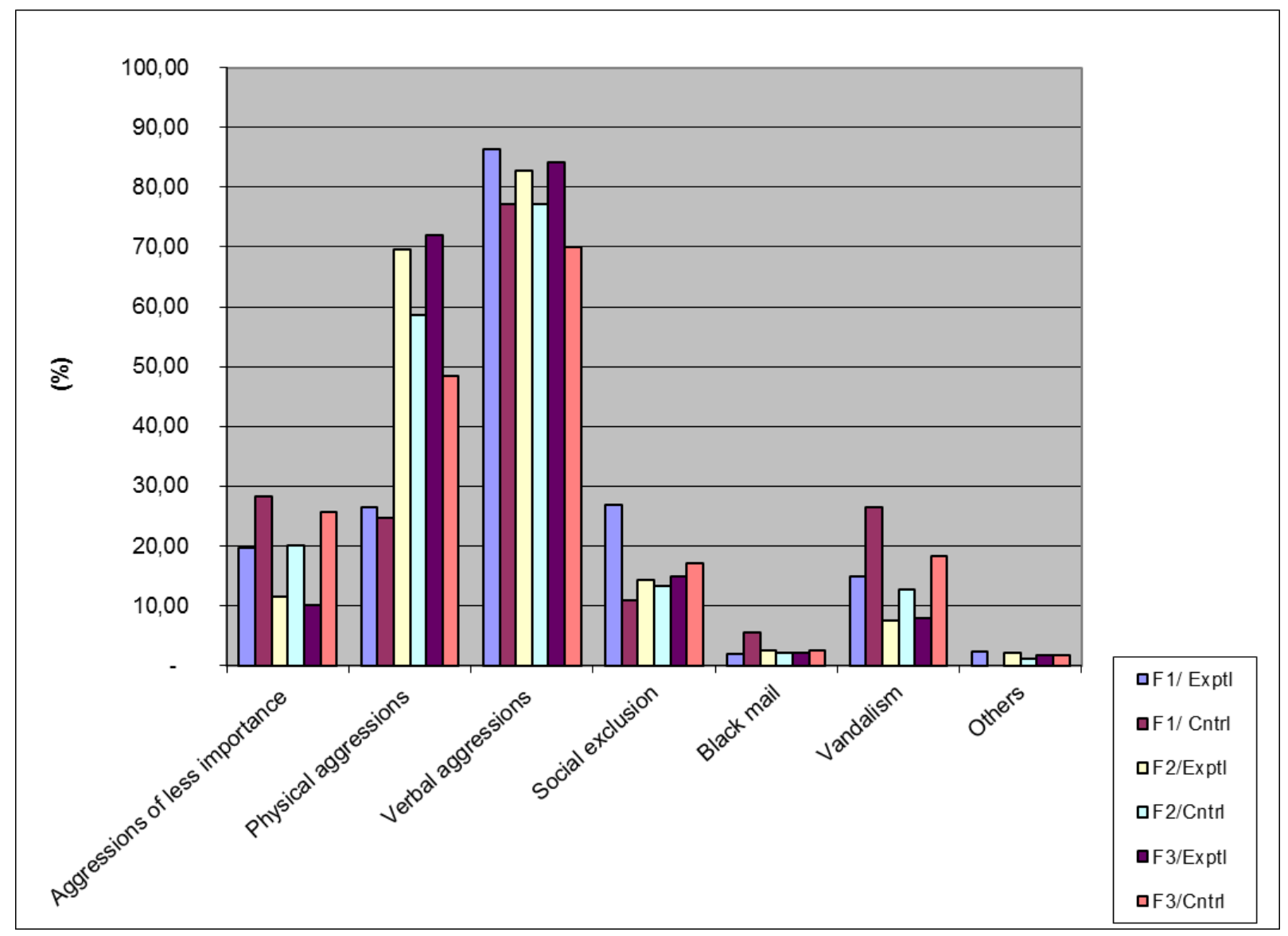

Figure 3: Type of aggression between students

\section{Bullying situation and personal experiences}

Concerning "Bullying situations", student questionnaires include two different types of items related to bullying situations: two questions that ask about the general incidence of bullying at school; and two others where students respond with regard to every type of bullying behavior (Never happens to me/I never do it, Sometimes happens to me/I sometimes do it, Very often happens to me/I usually do $i t^{1}$ ) (one question for victims, one question for bullies). No significant differences were found between schools or between phases in the experimental school.

${ }^{1}$ Very often happens to me/I usually do it: In order to simplify statistical analysis and compare with Ombudsman national results for Violence in Secondary schools, this category has unified very often and always, as they have been presented in the questionnaire. 
Practically none of the bullies recognize their participation in the episodes: the lowest frequency is found in the experimental school, though with significant differences between phase $2(27.9 \%)$ and $3(41.8 \%)\left[X^{2}(10)=19.29, p \leq .03\right]$. As for incidence of types of bullying behaviors from the victim's point of view, remarkable between-school differences were found, with a higher frequency of sexual harassment in phase $3\left[X^{2}(3)=7.84, p \leq .04\right]$ (Table 3). Neither the bullies from the experimental school nor those in the control school recognize any kind of behavior at a higher frequency (only in social exclusion, sometimes, in phase $2[X$ $\left.\left.{ }^{2}(3)=10.51, p \leq .01\right]\right)$.

Table 3. Sexual harassment incidence according to victims

\begin{tabular}{cccccccccccc}
\hline & \multicolumn{10}{c}{ I am sexually bullied } \\
\hline \multirow{2}{*}{ Phase } & \multirow{2}{*}{ Group } & \multicolumn{2}{c}{ Never } & \multicolumn{2}{c}{ Sometimes } & \multicolumn{2}{c}{ Very often } & \multicolumn{2}{c}{ n.a.. } & \multicolumn{2}{c}{ Total Group } \\
& & $\mathrm{N}$ & $\%$ & $\mathrm{~N}$ & $\%$ & $\mathrm{~N}$ & $\%$ & $\mathrm{~N}$ & $\%$ & $\mathrm{~N}$ & $\%$ \\
\hline \multirow{2}{*}{1} & Exptl. & 34 & $75.6 \%$ & 3 & $6.7 \%$ & 3 & $6.7 \%$ & 5 & $11.1 \%$ & 45 & $100.0 \%$ \\
\cline { 2 - 13 } & Cntrl. & 21 & $95.5 \%$ & 0 & $0.0 \%$ & 0 & $0.0 \%$ & 1 & $16.7 \%$ & 22 & $100.0 \%$ \\
\hline \multirow{2}{*}{2} & Exptl. & 31 & $66.0 \%$ & 1 & $2.1 \%$ & 2 & $4.3 \%$ & 13 & $27.7 \%$ & 47 & $100.0 \%$ \\
\cline { 2 - 13 } & Cntrl. & 25 & $86.2 \%$ & 2 & $6.9 \%$ & 1 & $3.4 \%$ & 1 & $3.4 \%$ & 29 & $100.0 \%$ \\
\hline \multirow{2}{*}{3} & Exptl. & 24 & $57.1 \%$ & 4 & $9.5 \%$ & 4 & $9.5 \%$ & 10 & $23.8 \%$ & 42 & $100.0 \%$ \\
\cline { 2 - 12 } & Cntrl. & 31 & $86.1 \%$ & 1 & $2.8 \%$ & 1 & $2.8 \%$ & 3 & $8.3 \%$ & 36 & $100.0 \%$ \\
\hline
\end{tabular}

On the other side of the situation, for victims of bullying or or other types of suffering, when asked about emotional support at school, students at both schools rarely select the option with nobody - with an average of $6.5 \%$ over all phases for both schools-, with differences seen in the last intake $\left[X^{2}(1)=6.43, p \leq .01\right]$.

Students' first choice out of ten options is classmates, with no differences between schools. Differences were found in the subitem families, though high percentage choices in phases 1, 2 and 3 are greater for the experimental group $\left[X^{2}(1)=5.76, p \leq .01\right]$. Classroom delegate is selected by few students and presents differences at every intake: $1\left[X^{2}(1)=4.76\right.$, $\mathrm{p} \leq .02] ; 2\left[X^{2}(1)=5.01, p \leq .02\right]$ and $\left.3\left[X^{2}(1)=6.29, p \leq .01\right]\right)$. On the other hand, with higher percentages in the control group, differences were also found for another teacher $[X$ $\left.{ }^{2}(1)=5.9, p \leq .01\right]$ and for other staff, in phase $2\left[X^{2}(1)=4.28, p \leq .03\right]$

\section{Frequency and types of aggression and conflicts from teachers' perspective}

According to the information reported by teachers, not many changes in the school climate were found between the two data intakes in the experimental school. At the same time, though both groups share a high number of contextual characteristics of culture and organiza- 
tion, they are differentiated in certain indicators related to conflict detection and prevention strategies, social relationships and interactions between students and teachers, disruption control and bullying actions taken by teachers in their classrooms. These are discussed below.

\section{Frequency and types of agression and conflicts}

Teachers from both schools have similar opinions about the frequency of conflicts in their schools, as there are no differences between means on the Likert scale 1-5. On the other hand, when asked about the type of aggressions between students, differences were found in verbal aggression -the most frequent conflict in both schools- and social exclusion.

In the first case, differences between schools are between pre $\left[X^{2}(1)=5.17 p \leq .02\right]$ and post-test $\left[X^{2}(1=11.42, p \leq .001]\right.$ Social exclusion separate the two groups in the last data intake $\left[X^{2}(1)=4.25, p \leq .03\right]$. According to teachers, the most frequent conflict in student aggression toward themselvesis verbal, , and between-school differences were found in the sub-item "students have made public mockery of you" $\left[X^{2}(1)=4.84, \mathrm{p} \leq .02\right]$, with a higher incidence in the control school in the last phase. Referring particularly to classroom conflicts, students' manners and lack of respect for teachers is the most frequent conflict, showing between-school differences only in the pre-test intake for the item bad manners and aggression between students $\left[X^{2}(1)=6.84, p \leq .009\right]$.

\section{Disruption control strategies in the classroom}

When teachers answer the general question about their control of classroom disruption, they feel more optimistic in the first data intake (3.00), showing differences in the second phase in a negative sense (2.53), on a Likert scale of $1-4[F(1.56)=6.64, p \leq .05]$. Regarding the four disruptive behaviors asked about - hindering the functioning of the class, challenging the teacher's authority, not doing homework and destroying school materials- and the twelve teachers' corresponding actions to stop them, few differences were found between phases in the experimental group or between the two schools. Table 4 below shows the main measures taken by teachers (above 20\%) in one or two of the data intakes, as well as the differences between groups (even if they had been chosen by a small percentage of teachers). 
Table 4. Differences in the primary disruption control measures taken by teachers in their classrooms.

\begin{tabular}{|c|c|c|c|c|c|c|c|}
\hline \multirow[t]{2}{*}{ MEASURE } & \multirow[t]{2}{*}{ GROUP } & \multicolumn{3}{|c|}{$\begin{array}{c}\text { Phase 1 } \\
\text { PRE } \\
\text { INTERVENTION }\end{array}$} & \multicolumn{3}{|c|}{$\begin{array}{c}\text { Phase 3 } \\
\text { POST } \\
\text { INTERVENTION }\end{array}$} \\
\hline & & $\%$ & $\chi^{2}(1)$ & $\mathbf{p}$ & $\%$ & $\chi^{2}(1)$ & $\mathbf{p}$ \\
\hline \multicolumn{8}{|c|}{ A student hinders the functioning of the class } \\
\hline \multirow{2}{*}{$\begin{array}{l}\text { I give a verbal warning at this } \\
\text { moment }\end{array}$} & Exptl. & 50.0 & & & 40.0 & \multirow{2}{*}{4.28} & \multirow{2}{*}{0.03} \\
\hline & Contrl & 73.1 & & & 68.0 & & \\
\hline \multirow{2}{*}{$\begin{array}{l}\text { I move him/her apart from the } \\
\text { group }\end{array}$} & Exptl. & 25.0 & \multirow{2}{*}{4.78} & \multirow{2}{*}{0.02} & 10.0 & & \\
\hline & Contrl & 3.8 & & & 4.0 & & \\
\hline \multicolumn{8}{|c|}{ A student challenges teacher authority } \\
\hline \multirow{2}{*}{ I call the student aside } & Exptl. & 51.7 & \multirow{2}{*}{9.00} & \multirow{2}{*}{0.003} & 33.3 & & \\
\hline & Contrl. & 12.5 & & & 24.0 & & \\
\hline \multirow{2}{*}{ I take disciplinary actions } & Exptl. & 13.8 & \multirow{2}{*}{9.82} & \multirow{2}{*}{0.002} & 30.0 & & \\
\hline & Contrl & 54.2 & & & 52.0 & & \\
\hline \multicolumn{8}{|c|}{ A student destroys teaching materials } \\
\hline \multirow{2}{*}{$\begin{array}{l}\text { I encourage the whole group to } \\
\text { be involved in the resolution... }\end{array}$} & Exptl. & 51.7 & \multirow{2}{*}{14.66} & \multirow{2}{*}{0.0001} & 0.0 & & \\
\hline & Contrl. & 4.0 & & & & & \\
\hline I take disciplinary actions & Exptl. & 3.4 & 14.57 & 0.0001 & 28.6 & 4.05 & 0.04 \\
\hline
\end{tabular}

Anti-bullying strategies in the classroom

Of the twelve bullying behaviors asked about and the twelve teachers' corresponding actions to stop them, between-teacher differences were found in all bullying categories at both schools. The criteria for selecting measures to include in the next table are the same as those used above(Tables 5 and 6).

Table 5. Differences in the primary measures taken by teachers for controlling bullying in their classrooms (1)

\begin{tabular}{|c|c|c|c|c|}
\hline \multirow[t]{2}{*}{ MEASURE } & \multirow[t]{2}{*}{ GROUP } & $\begin{array}{c}\text { Phase 1 } \\
\text { PRE } \\
\text { INTERVENTIO } \\
\mathbf{N}\end{array}$ & \multicolumn{2}{|c|}{$\begin{array}{c}\text { Phase 3 } \\
\text { POST } \\
\text { INTERVENTION }\end{array}$} \\
\hline & & $\% \quad \chi^{2}(1)$ & $\%$ & $\chi^{2}(1)$ \\
\hline \multicolumn{5}{|c|}{ A student habitually ignores a classmate } \\
\hline \multirow{2}{*}{ I ignore the situation } & Exptl. & 6.5 & \multirow{2}{*}{4.74} & \multirow{2}{*}{0.02} \\
\hline & Contrl. & 8.3 & & \\
\hline \multirow{2}{*}{$\begin{array}{l}\text { I tell my colleagues and listen to } \\
\text { their advice }\end{array}$} & Exptl. & 19.4 & \multirow[b]{2}{*}{4.74} & \multirow[b]{2}{*}{0.02} \\
\hline & Contrl. & 16.7 & & \\
\hline
\end{tabular}




\begin{tabular}{|c|c|c|c|c|c|c|}
\hline \multicolumn{7}{|c|}{ A student habitually insults a classmate } \\
\hline \multirow{2}{*}{ I call the student aside } & Exptl. & \multirow{2}{*}{7.23} & \multirow{2}{*}{0.007} & 37.0 & & \\
\hline & Contrl. & & & 20.0 & & \\
\hline \multirow{2}{*}{ I take disciplinary actions } & Exptl. & \multirow{2}{*}{5.64} & \multirow{2}{*}{0.01} & 25.9 & & \\
\hline & Contrl. & & & 16.0 & & \\
\hline \multicolumn{7}{|c|}{ A student habitually calls someone offending names } \\
\hline \multirow{2}{*}{ I ignore the situation } & Exptl. & 0.0 & & 0.0 & \multirow{2}{*}{-3.84} & \multirow{2}{*}{0.05} \\
\hline & Contrl. & 4.2 & & 12.5 & & \\
\hline \multicolumn{7}{|c|}{ A student habitually steals things from someone } \\
\hline \multirow{2}{*}{$\begin{array}{l}\text { I talk to the teacher in charge of the } \\
\text { group or to the School Administrator }\end{array}$} & Exptl. & \multirow{2}{*}{-4.15} & \multirow{2}{*}{0.04} & 56.0 & & \\
\hline & Contrl. & & & 45.8 & & \\
\hline \multirow{2}{*}{ It doesn't happen } & Exptl. & \multirow{2}{*}{-5.41} & \multirow{2}{*}{0.02} & 8.0 & & \\
\hline & Contrl. & & & 0.0 & & \\
\hline \multicolumn{7}{|c|}{ A student habitually hits someone } \\
\hline \multirow{2}{*}{$\begin{array}{l}\text { I give a verbal warning at this mo- } \\
\text { ment }\end{array}$} & Exptl. & 34.6 & & 17.9 & 3.9 & \multirow{2}{*}{0.04} \\
\hline & Contrl. & 26.1 & & 43.5 & 9 & \\
\hline \multirow{2}{*}{ I call the student aside } & Exptl. & 38.5584 & \multirow{2}{*}{0.01} & 10.7 & & \\
\hline & Contrl. & 8.75 .84 & & 4.3 & & \\
\hline \multirow{2}{*}{ I throw him/her out of class } & Exptl. & $26.9,55$ & \multirow{2}{*}{0.03} & 21.4 & & \\
\hline & Contrl. & 4.34 .55 & & 17.4 & & \\
\hline \multirow{2}{*}{ I take disciplinary actions } & Exptl. & & \multirow{2}{*}{0.04} & 32.1 & 4.2 & \multirow{2}{*}{0.04} \\
\hline & Contrl. & $30.44^{4.21}$ & & 60.9 & 0 & \\
\hline \multirow{2}{*}{ It doesn't happen } & Exptl. & 3.8779 & 0005 & 10.7 & & \\
\hline & Contrl. & -7.79 & 0.000 & 8.7 & & \\
\hline
\end{tabular}

Table 6. Differences in the primary bullying control measures taken by teachers in their classrooms $(2)$

A student habitually threatens someone just to scare him/her

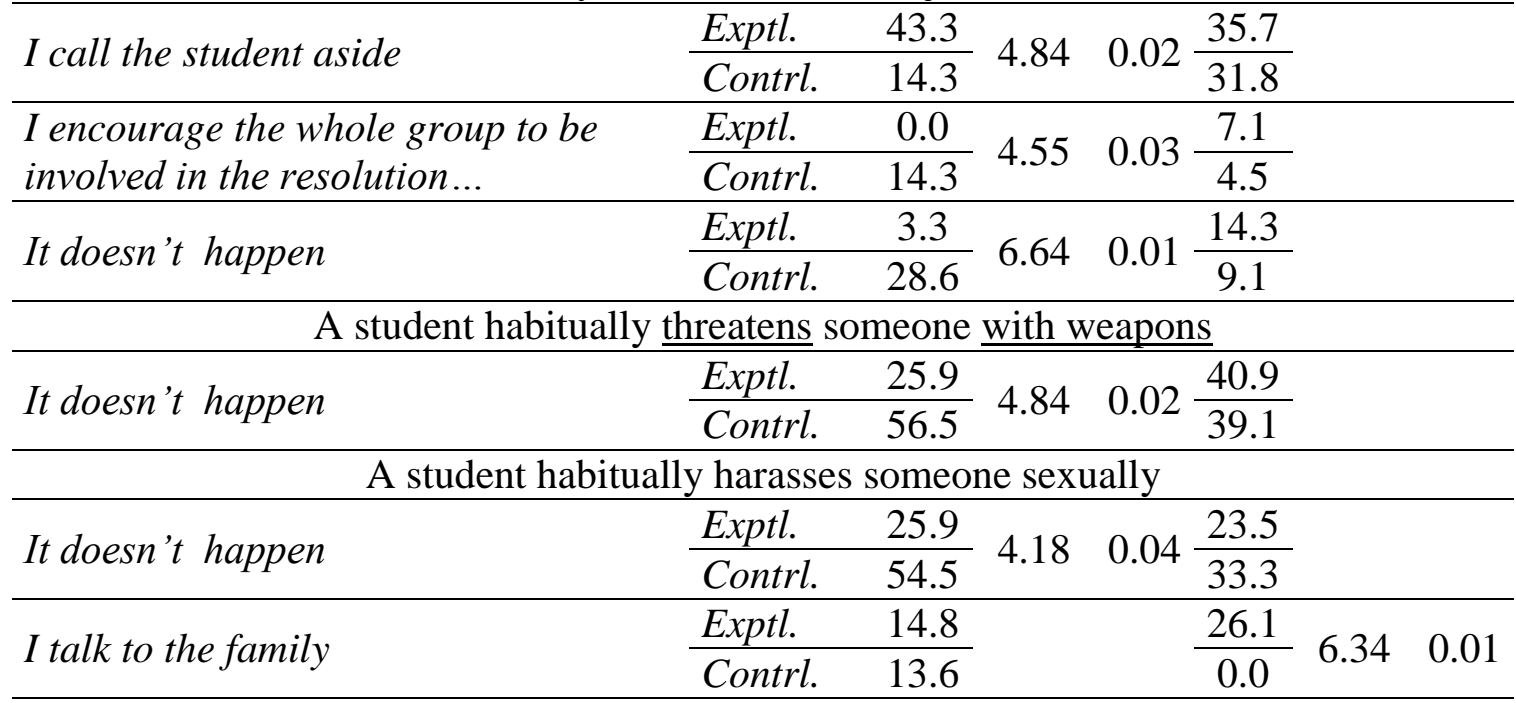




\section{Program implementation}

\section{Students' and teachers' perceived efficacy}

The results of the data analysis from a brief questionnaire, along with the climate in the experimental school, whether in phase 2 (students only) or phase 3 (students and teachers) show general agreement about an understanding of the program, and the figures who primarily administer it (helper students), for both groups of teachers and students (Figure 4)

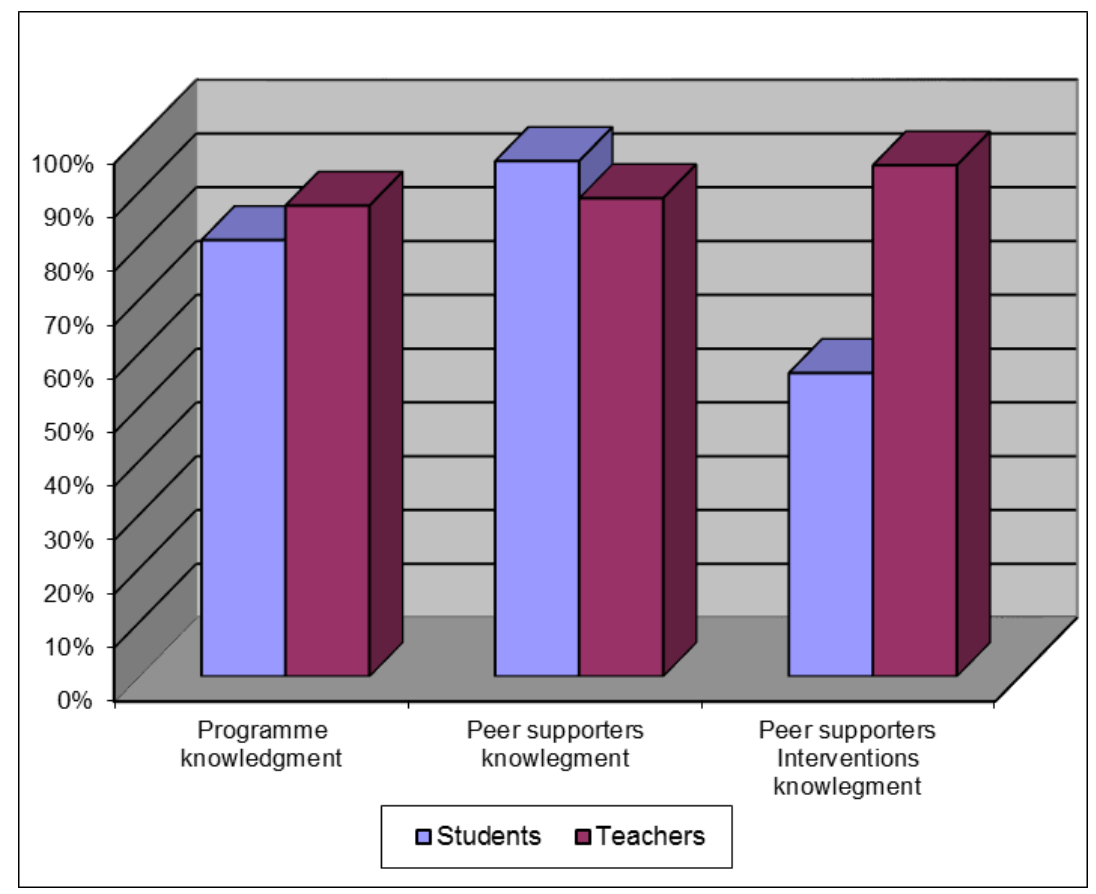

Figure 4. An understanding of the program, the peer helper in the classroom and his/her interventions

The same agreement between the two groups is found in affirmative responses to its usefulness for improving the climate (Figure 5), with high percentages of positive answers also in the assessment of helpers' interventions (Figure 6). 


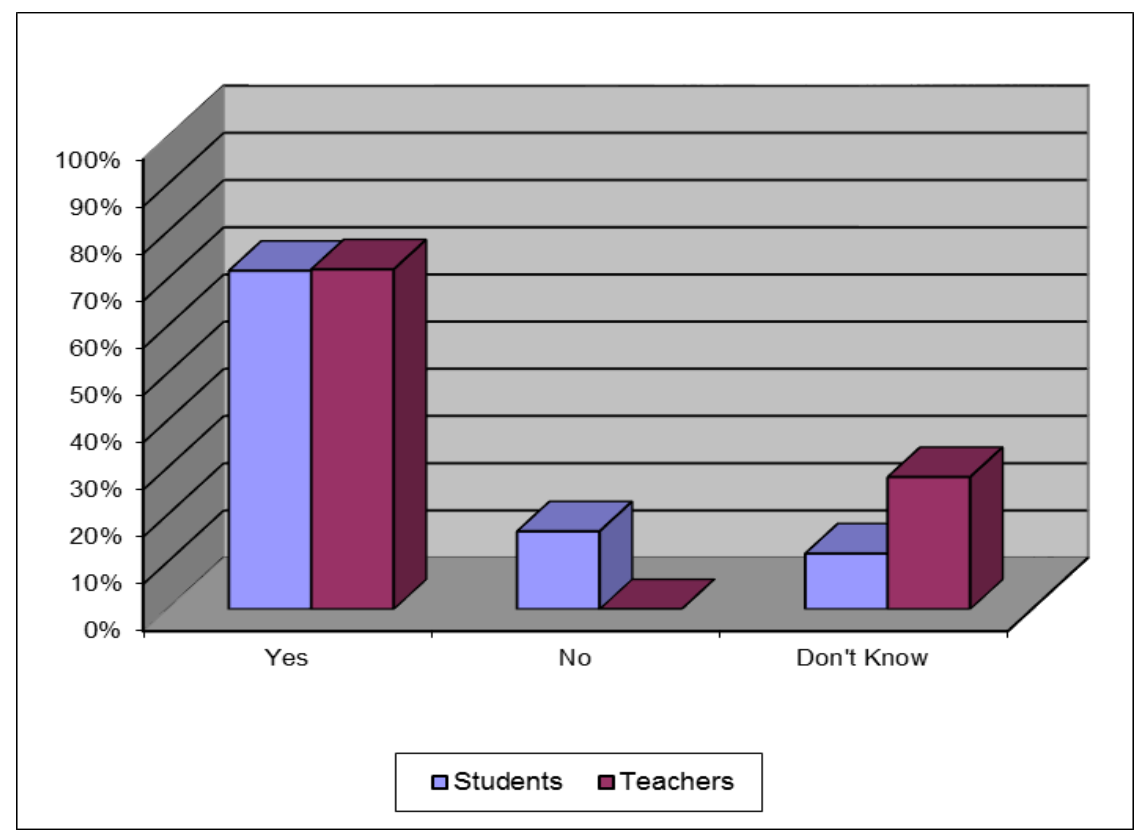

Figure 5: Influence of the program on the school climate

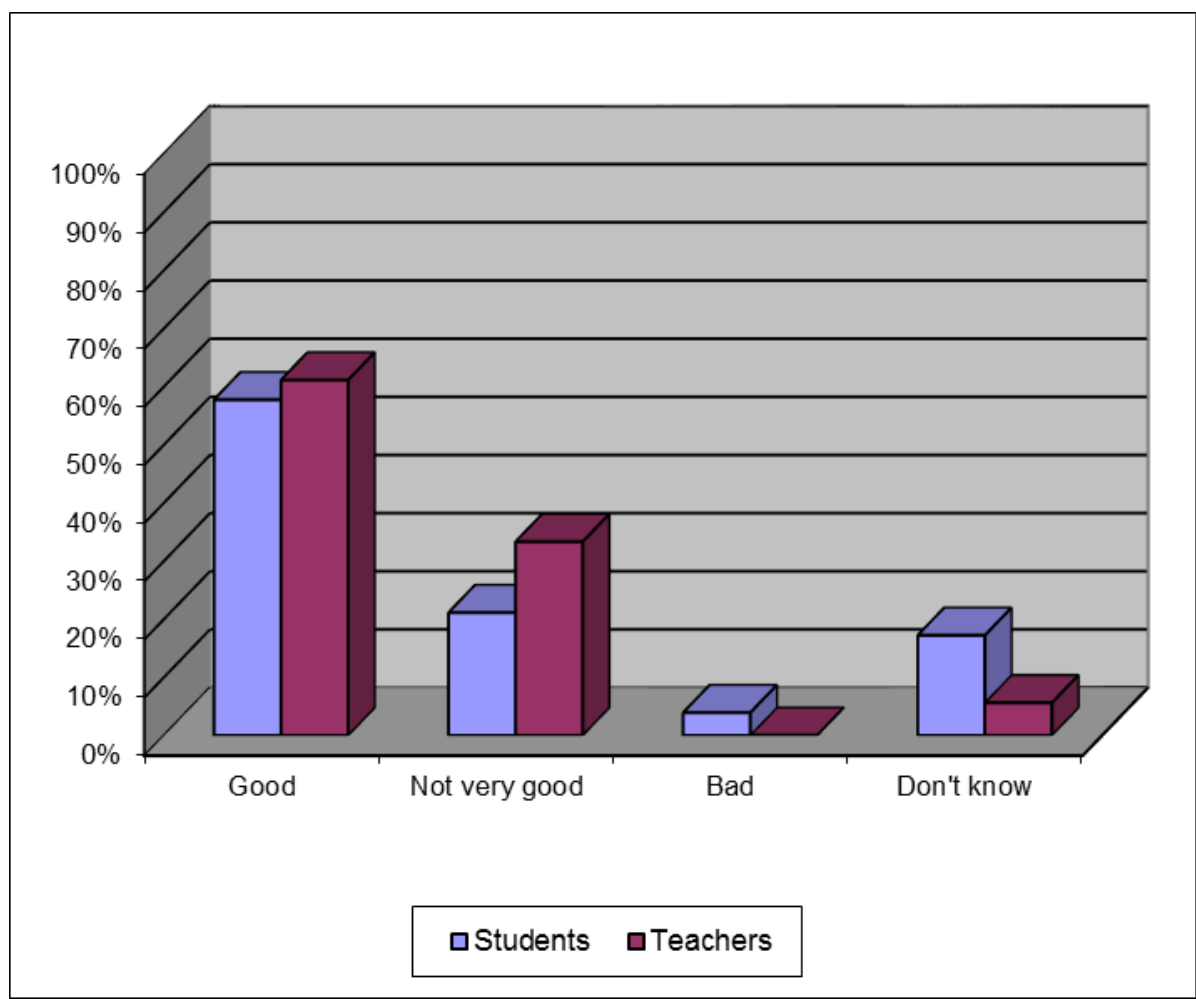

Figure 6: Evaluation of peer helper interventions

\section{Program by the School Administrators}

The main points obtained from in-depth interviews with the two school administrators in charge of program implementation are summarized as follows: 
General assessment of the program is positive, both persons sharing their firm agreement about continuing the program in the future. Despite the special difficulties of the social context, both consider that the program has worked well, showing a capacity to cushion the impact of conflicts and to promote social and moral development of the students involved.

The program has turned out to be an effective instrument in preventing conflicts (or stopping their escalation when they have already appeared). It has also promoted positive relationships between students, e.g. successfully detecting and intervening in bullying cases, helping to integrate new students, etc. It is less useful in disruption-related conflicts between teachers and students (where the conventional school rules traditionally act).

The program has helped to construct a new culture of participation, as it has offered the possibility of real student involvement in the resolution of everyday conflicts, encouraged by a shared responsibility in the creation and maintenance of a healthy school climate. Nevertheless, both administrators report limitations to its influence on the school climate as a whole, because of the complexity of its implementation in the current school social organization.

\section{Discussion}

The general objective of this study was the assessment of a school intervention program based on peer support systems, as compared to a control group. It belongs to the few assessments that are based on the comparison between an experimental and a control group, and have not produced direct significant results (Cowie \& Smith, 2013; Smith \& Salmivalli, 2011; Svensson, 2003; Thompson \& Smith, 2013)

The detailed analysis of the effects on school climate presented in this work reveals the particularly difficult situation of the experimental school, as reflected in an overall increase of conflicts and the consequent deterioration of relationships between students and teachers in general. In the classroom, on the other hand, support for emotional problems increases and there is a decrease in disruptive behavior (usually chosen as the most important problem in the school). This change seems to indicate an increase, towards the end of the second year, in the possibilities of receiving help from classmates in times of need. In any case, 
the majority indicate that they can count on some classmates, followed by their parents, siblings or older friends and, finally, their teachers. This could be related to the presence of the program.

An analysis of the conflicts at the school level shows, in turn, a drastic increase in physical aggressions as one of the most striking changes; however, the conflicts most reported by students were verbal aggression between students, of very high incidence (hypothesis two). At the same time, the experimental school shows decreases in social isolation, theft and vandalism, this being compatible with the information regarding the general increase of conflicts in the last phase of the study. In this way, along with the previous, and further noting the high incidence of disrespectful behaviour by students towards teachers, students also report an increase in frequency of disrespectful behaviour towards them by some of the teachers, although in percentages they are notably fewer than the conflicts mentioned above.

Rounding out this information with the incidence of bullying, in which no differences were found between the schools, it should be first noted that there is a lack of change when asked about abuse in general during the study's two year duration. In total, six percent of students admit to being frequently victimized, a rate that is higher than the data provided by most studies, although they do concur in that the most frequent conflicts are verbal aggression (Defensor del Pueblo-UNICEF, 2000; 2007). The control school, in turn, presents very similar results to the experimental school in certain indicators, although they differ at other moments of the evaluation. This finding shows, as hypothesized, that the perception of conflicts was different at the two schools. In the first place, there is a strikingly different evolution of the frequency of conflicts in the general sphere of the school, with a sharp decline in the control group. Physical aggressions, especially, separate the schools in the last phase. In the last phase of the study, a difference in the direction of an increase in class disruptions, and in theft and vandalism, being greater in the control school, can be observed according to the information provided by students.

Although there are not many differences between the schools regarding bullying, certain differences can be observed in more serious types: sexual harassment, in which the experimental school rates a frequency three times higher than that of the control school. Another important detail resulting from a comparison of the two schools, is the data gathered about the emotional support received by the victims (its absence and of the people receiving support): in 
the last phase of the study, the control group reporting the absence of support is significantly higher at the control school than at the experimental school. At the same time, support from the family is also greater in the former.

According to the information provided by teachers, just as verbal aggressions between students - a conflict of very high incidence in both schools - are more frequent in the experimental school, the most striking difference in the last phase is the increase in social isolation in the control school. Also from the teachers' perspective, those who work at the control school are mocked by students more often than at the experimental school. Even so, no important differences have been observed, generally speaking, in the interpersonal relationships between teachers, students-teachers, and teachers-administrators at both schools at the end of the study. In terms of the course of action taken by teachers faced with class disruptions and abusive behavior, and the measures taken to deal with or prevent them, both schools are similar to a large degree, with few exceptions. With regard to class disruptions, the difference in the last phase points to the more frequent use, in the control school, of verbal reprimands to the student disrupting the class, as well as a greater use of disciplinary actions. The bullying cases observed by teachers point to differences in the last phase in different types of behaviors: with social isolation, the control teachers seemed to intervene more than the experimental school teachers, they also reported doing so in the case of verbal and physical aggression, with one exception: with sexual harassment, in which teachers say they inform the families. Consistent with the information provided by students, who point to the importance of this conflict at the school, teachers from the experimental school do seem concerned with intervening.

Regarding school-wide evaluation of the program and based on the data provided by its beneficiaries and by teachers, we note the high marks received for degree of awareness of the program, the helpers and their actions. This data generally concurs with that obtained in previous studies in the field (Cowie, 1998; Cowie, Naylor, Talamelli, Chauhan \& Smith, 2002; Naylor \& Cowie, 1999; Naylor, Cowie \& Del Rey, 2001;). The result also confirms our third hypothesis.

About the interventions, although they receive a positive rating from most of the teachers and students, they seem to be less valued by one group. The reason for this might be found in the confidential nature of interventions, which would prevent raters from obtaining 
the level of knowledge necessary for evaluating them more precisely. Nevertheless, a large majority from both groups consider the program to be useful for improvemingrelationships at school, this being one of the program's success indicators.

The two school administrators interviewed also rated the program very positively. When analysing the especially difficult situation the schools were experiencing at the time of the program's introduction, they mention the importance of its presence in easing of the impact of conflicts. Both administrators reiterate the program's ability to act as an instrument of prevention and for improving interpersonal relationships, especially between students (more than in conflicts with teachers in the classroom). The link they establish between the peer helpers' direct participation in the program and their social and ethical development is very relevant in itself, while pointing out the importance of experience for learning the values needed for establishing good relationships.

The cases of peer helper intervention in bullying situations deserve special attention. It is not difficult to conceive that the complex circumstances derived from the physical and social environment in which the school is located, especially during the first two years of the program's implementation, made greater visibility of peer helper actions more difficult, hindering the positive repercussions of these actions on the overall school climate. The three levels of prevention within the program, firstly, in the orientation of the training offered, secondly, in the detection of and first intervention in cases that were encountered through the program, and thirdly, in the course of action taken by the peer helpers directed toward recovery in students who have experienced abuse, are all present in the exciting reports of their interventions provided by the Head Teacher and the Director of Studies (school administrators), although for lack of space it is not possible to include them here (Andrés, 2009a). But it seems relevant to mention them since, on the prevention-remedy continuum of educational action, opportunities for social and ethical learning appear, which the professionals responsible for the project mention in their reports. 
Limitations of the study, future research lines and theoretical-practical implications of the findings

We acknowledge a certain number of limitations in this study. Firstly, it would have been valuable to do a longitudinal follow up of the pupils and teachers, if the population were more stable from one year to the other.

Other limitations stem from the program's ability to achieve an improved school climate. Precisely in this aspect, our results diverge from those found in previous studies. The increase in conflicts mentioned above has been observed in other schools, also after program implementation (BRÁ, 1999, quoted in Svensson, 2003; Salmivalli, Kaukiainen \& Voeten, 2005; Salmivalli, Kaukiainen, Voeten \& Sinisammal, 2004; Smith, 2003). Just as in our case, this information is partly attributable to the effect of awareness and consciousness that the program produces when being introduced. These results also highlight the inherent limits to "a perceptive approach" which relies on the sensations of people and the influence of normative models. Thus Gaymard and Andrés (2009) have shown the complexity of representation when young high school students are asked to answer a questionnaire on social skills according to different pro and con normative instructions. The information indicates an increase in conflicts which occurs in parallel to the implantation and positive evaluation of the program by students and teachers, a paradoxical result that was also found in the previous literature (Andrés, 2009; Cowie \& Fernandez, 2006; Cowie \& Olafsson, 2001; Houston, Smith \& Jessel, 2009, 2011; Naylor \& Cowie 1999, Svensson, 2003). In this regard, it is considered a useful tool to improve safety at the school, even with a perception of reduced bullying (Cowie \& Olafsson, 2001; Cowie \& Smith, 2013; Naylor \& Cowie, 1999). Nevertheless, there is a need to design successive evaluations of the programs over the course of several years of functioning, from which we might expect relevant contributions to the social-emotional climate of the school. In this sense, a very recent work by Cowie (2014) indicates that peer support can be extremely effective in creating emotionally healthy relationships in the whole school community (p. 30)

As some researchers have already indicated (Cowie \& Smith, 2013), it is essential to continue to increase the peer group's understanding of the roles and motivations of bullying. In recent years, moreover, cyberbullying has acquired special importance, as a new form of 
bullying with its own characteristics, for which different procedures and interventions must be developed (Mora - Merchán \& Jäger, 2010).

Finally, we must bear in mind other types of difficulties that could arise from the implementation of these programs, inasmuch as it is necessary to incorporate them into the daily organization of schools, thus ensuring their continuity. In this way, organizational rigidity, added to the lack of decisive support from the Administration, could be an important obstacle to success. In any case, these types of programs point the way towards building positive interpersonal relationships at school: their contribution to the culture of participation and shared responsibility in the management of a cooperative atmosphere encourages the progress of not only of those directly involved, but also of the educational institution as a whole.

\section{References}

Amidon, E.J. \& Hough, J.B. (1967). Interaction Analysis: Theory Research and Application. Boston: Addison-Wesley.

Andrés, S. (2009). Los sistemas de ayuda entre iguales como instrumentos de mejora de la convivencia en la escuela: evaluación de una intervención. [Peer help systems as instruments for improved coexistence at school: assessment of an intervention.] Madrid, Spain: Ministerio de Educación. Instituto de Formación del profesorado, Investigación e Innovación Educativa (IFIIE)

Andrés, S. \& Barrios, A. (2006). The model of student helper under discussion: opinion of participating students and their beneficiaries. Electronic Journal of Research in Edu cational Psychology, 4(2), 160-174.

Andrés, S., Barrios, A. \& Martín, E. (2005). Evaluación de un programa de ayuda entre iguales en Educación Secundaria por medio de grupos de discusión: la opinión de los alumnos participantes. [Evaluation of a peer help system in secondary education, through discussion groups: the participating students' opinions.] In J. A. Del Barrio \& I. Fajardo (Eds.), Nuevos contextos psicológicos y sociales en educación. Buscando respuestas (pp. 33-47). Santander, Spain: INFAD, Psicoex.

Andrés, S., Gaymard, S. \& Martín, E. (2005). Evaluación de la competencia social en el contexto escolar: la experiencia de un programa de ayuda entre iguales en adolescentes de 
secundaria. [Assessing the social competency in the school context: the experience of a peer help program in adolescents at secondary school.] In J. A. Del Barrio \& I. Fajardo (Eds.), Nuevos contextos psicológicos y sociales en educación. Buscando respuestas (pp. 17-32). Santander, Spain: INFAD, Psicoex.

Andrés, S. \& Martín, E. (2002). Evaluación de programas basados en el sistema de ayuda entre iguales. [Evaluation of programs based on a peer help system.] In I. Fernández, E. Villoslada \& S. Funes (Eds.), Conflicto en el centro escolar. El modelo del alumno ayudante como estrategia de intervención educativa (pp. 239-261). Madrid, Spain: La Catarata.

Barrios, A., Andrés, S., \& Granizo, L. (2011). El asesoramiento para la mejora de la convivencia y el clima de centro. [Advising for improved coexistence and school climate.] In E. Martín \& J. Onrubia (Eds.), Orientación Educativa. Procesos de innovación y mejora de la enseñanza (15-76). Barcelona, Spain: Graó.

Boulton, M.J., Trueman, M., Chau, C., Whitehand, C. \& Amatya, K. (1999). Concurrent and longitudinal links between friendship and peer victimisation: implications for befriending interventions. Journal of Adolescence, 22, 1999, 461-466.

Cowie, H. (1998). Perspective of teachers and pupils on the experience of peer support against bullying. Educational Research and evaluation, 4(2), 108-125. DOI: 10.1076/edre.4.2.108.6958

Cowie, H. (2014). Understanding the Role of Bystanders and Peer Support in School Bullying. The International Journal of Emotional Education, 6-1, 26-32.

Cowie, H. \& Jennifer, D. (2007). Managing Violence in Schools: a Whole-School Approach to Best Practice. London, UK: Sage.

Cowie, H. \& Jennifer, D. (2008). New Perspectives on Bullying. Glasgow, UK: Open University Press.

Cowie, H., Jennifer, D., Chankova, D., Poshtova, T., Deklerck, J., Deboutte, G., Ertesvåg, S. K., Samuelsen, A. S., O’Moore, M., Minton, S. J., Ortega, R. \& Sanchez, V. (2007) School Bullying and Violence: Taking Action. http://www.vista-europe.org

Cowie, H., Naylor, P., Tallamelli, L., Chauhan, P. \& Smith, P.K. (2002). Knowledge, use of and attitudes toward peer support: a 2-year follow-up to the Prince's Trust survey. Journal of Adolescence, 25, 453-467. 
Cowie, H. \& Olafsson, R. (2000). The role of peer support in helping the victims of bullying in a school with high levels of aggression. School Psychology International, 21(1), 7995.

Cowie, H. \& Sharp, S. (1996). Peer Counselling in schools. London, UK: David Fulton Pub lishers.

Cowie, H. \& Smith, P. K. (2013). La ayuda entre iguales como instrumento para la mejora de la seguridad en los centros educativos y para la reducción del bullying y la violencia. [Peer help as an instrument for improved safety at schools and for reduced bullying and violence.] In A. Ovejero, P.K. Smith \& Yubero, S. (Coords.) El acoso escolar y su prevención. Perspectivas internacionales. (pp. 263-285). Madrid: Biblioteca Nueva.

Cowie, H. \& Wallace, P. (2000). Peer Support in Action. From standing by to stand by. London, UK.: Sage Publications.

Defensor del Pueblo-UNICEF (2007). Violencia escolar: el maltrato entre iguales en la ESO 1999-2006 (Nuevo estudio y actualización del Informe 2000). [School violence: bullying in compulsory secondary education 1999-2006 (new study and update of the Year 2000 Report.] Madrid, Spain: Publicaciones de la Oficina del Defensor del Pueblo.

http://www.defensordelpueblo.es/documentacion/informesmonograficos/ViolenciaEsc olar2006.pdf

Del Barrio, C., Barrios, A., Granizo, L., Van der Meulen, K, Andrés, S. \& Gutiérrez, H. (2011). Contribuyendo al bienestar emocional de los compañeros: evaluación del Pro grama Compañeros Ayudantes en un instituto madrileño. [Contributing to the emotional well being of classmates: an evaluation of the Helping Classmates Program at a Madrid secondary school.] European Journal of Education and Psychology, 4(1), 5-17.

Fernández, I., \& Quevedo, G. (1992). ¿Cómo desenmascarar lo que no se deja ver? La violencia en la escuela. [How to uncover what is being hidden? Violence at school.] In C. Borrego (Ed.), Curriculum y desarrollo sociopersonal. Sevilla, Spain: Alfar.

Fernández, I.; Villaoslada, E. \& Funes, S. (2002). Conflictos en el centro escolar. El modelo del alumno ayudante como estrategia de intervención educativa. [Conflicts at school. The student helper model as an educational intervention strategy.] Madrid, Spain: La Catarata. 
Flanders, N. A. (1964). Some relationships between teacher influence, pupil attitudes and achievement. In B.J. Bilddle \& W.J. Ellena (Eds.), Contemporary research on teacher effectiveness. Austin (Texas): Holt Rinehart and Winston.

Gaymard, S., \& Andrés, S. (2009). Représentations, modèles normatifs et compétences sociales: une étude exploratoire dans un lycée sensible en Espagne. [Representations, normative models and social competencies : an exploratory study in a Spanish secondary school.] Revue Internationale de Psychologie Sociale, 2, 43-69.

Gaymard, S., Andrés, S. \& Fernández, I. (2002). Une étude du climat scolaire dans une école secondaire espagnole. [A study of school climate in a Spanish secondary school.] Revue de Psychologie de l'Education, 5, 55-87.

Hargreaves, D. (1978). Interpersonal relations and Education. London, UK: Routledge \& Kegan Paul.

Houlston, C., Smith, P.K. \& Jessel, J. (2009). Investigating the extent and use of peer support initiatives in English schools. Educational Psychology, 29 (3), 325-344.

Houlston, C., Smith, P.K. \& Jessel, J. (2011). The Relationship between use of School-Based Peer Support Initiatives and the Social and Emotional Well-Being of Bullied and NonBullied Students. Children \& Society, 25(4), 293-305. DOI: 10.1111/j.10990860.2011.00376.x

Ley Orgánica 2/2006, de 3 de mayo, de Educación (L.O.E.). Boletín Oficial del Estado (04/05/06), 106, 17.158-17.207. Madrid, Spain: Ministerio de Educación.

Martín, E., Fernández, I., Andrés, S., Del Barrio, C. \& Echeita, G. (2003). La intervención en los centros escolares: mejora de la convivencia y prevención de conflictos. [Intervention in schools: improving coexistence and preventing conflicts.] Infancia y Aprendizaje, 26(1), 79-95.

Mental Health Foundation (2002). Peer support: Someone to turn to. An evaluation report of the Mental Health Foundation Peer Support Programme. London \& Glasgow, UK: Mental Health Foundation.

Mora Merchán, J. \& Jäger, T. (eds.) (2010). Cyberbullying: A Cross-national Comparison. Landau: Germany. 
Naylor, P. \& Cowie, H. (1999).The effectiveness of peer support systems in challenging school bullying: the perspectives and experiences of teachers and pupils. Journal of Adolescence, 22, 462-479.

Naylor, P., Cowie, H. \& Del Rey, R. (2001). Coping Strategies of Secondary Children in Response to Being Bullied. Child Psychology and Psychiatry Review, 6(3), 114-120.

OECD (2009). Teaching and learning International Survey (TALIS). TALIS 2008. (Spanish report 2009: Estudio Internacional sobre la Enseñanza y el Aprendizaje. Madrid, Spain: Instituto de Evaluación. Ministerio de Educación).

Ovejero, A., Smith, P.K. \& Yubero, S. (Coords.) (2013). El acoso escolar y su prevención. [Harrassment at school and its prevention.] Perspectivas internacionales. Madrid: Biblioteca Nueva.

Ortega, R. \& Mora-Merchán, J.A. (1999). Spain. In P.K. Smith, Y. Morita, J. Junger-Tas, D. Olweus, R. Catalano \& P. Slee (Eds.) The nature of school bullying. A crossnational perspective. (pp. 157-173) London, UK.: Routledge.

Ortega, R., \& Del Rey, R. (2001). Aciertos y desaciertos del Proyecto Sevilla Antiviolencia Escolar (SAVE) [Hits and misses in the Seville School Anti-Violence Project (SAVE).] Revista de Educación, 324, 253-270.

Ortega, R., Del Rey, R. \& Mora-Merchán, J.A. (2004). SAVE model: an anti-bullying intervention in Spain”. In P.K. Smith, D. Pepler \& K. Rigby (Eds.), Bullying in schools. How successful can interventions be? (pp.167-185). Cambridge, UK: Cambridge University Press.

Pepler, D.J. \& Craig, W.M. (2000). Making a difference in bullying. LaMarsh report 59. Toronto: York University.

Pepler, D.J., Smith, P.K. \& Rigby, K. (2004). Looking back and looking forward: implications for making interventions work effectively. In P.K. Smith, D. Pepler \& K. Rigby (Eds.), Bullying in schools. How successful can interventions be? (pp. 307-324). Cambridge, UK: Cambridge University Press.

Piaget, J. (1932). Le jugement moral chez l'enfant. [Moral judgment in a child's home.] Paris, Fr.: Alcan. 
Del Rey, R., \& Ortega, R. (2001). El programa de ayuda entre iguales en el contexto del pro yecto Sevilla Antiviolencia Escolar. [The peer help program in the context of the Seville School Anti-Violence Project.] Revista de Educación, 326, 297-310.

Salmivalli, C. (1998). Intelligent, attractive, well-behaving, unhappy: the structure of adolescents' self-concept and its relations to their social behaviour. Journal of Research on Adolescence, 8, 333-354. Doi: 10.1207/s15327795jra0803_3

Salmivalli, C. (1999). Participant role approach to school bullying: implications for intervene tions. Journal of Adolescence, 22(4), 453-459. Doi: 10.1006/jado.1999.0239

Salmivalli, C. (2010). Bullying and the Peer Group: A Review. Aggression and Violent Behavior, 15 (2), 112-120. Doi: 10.1016/j.avb.2009.08.007

Salmivalli, C., Kärnä, A. \& Poskiparta, E. (2010). From peer putdowns to peer support: A theoretical model and how it translated into a national anti-bullying program. In $\mathrm{S}$. Jimerson, S. Swearer \& D. Espelage (Eds.), Handbook of Bullying in Schools: An International Perspective (pp. 441-454). New York: Routledge.

Salmivalli, C., Kaukiainen, A., \& Voeten, M. (2005). Antibullying intervention: Implementation and outcomes. British Journal of Educational Psychology, 75, 465-487. Doi: 10.1348/000709905X26011

Salmivalli, C., Kaukiainen, A., Voeten, M. \& Sinisammal, M. (2004). Targeting the group as a whole: the Finnish anti-bullying intervention. In P.K. Smith, D. Pepler \& K. Rigby (Eds.), Bullying in schools. How Successful Can Interventions Be? Cambridge, UK: University Press.

Salmivalli, C., Lagerspetz, K., Björkqvist, K., Österman, K. \& Kaukianen, A. (1996). Bullying as a group process: Participant role their relation to social status within the group. Aggressive Behaviour, 22, 1-15.

Salmivalli, C. \& Voeten, M. (2004). Connections between attitudes, group norms, and behave ior in bullying situations. International Journal of Behavioral Development, 28, $246-$ 258. Doi: $10.1080 / 01650250344000488$

Sharp, S. y Cowie, H. (1998). Counselling and Supporting Children in Distress. London: Sage.

Smith, P.K. (Ed.) (2004). Violence in schools. The response in Europe. London, UK: RoutledgeFalmer. 
Smith, P.K., Morita, Y., Junger-Tas, J., Olweus, D., Catalano, R., \& Slee, P. (Eds.) (1999). The nature of school bullying. A cross-national perspective. London: Routledge.

Smith, P.K., Pepler. D. \& Rigby, K. (Eds.) (2004). Bullying in schools. How Successful Can Interventions Be? Cambridge, UK: Cambridge University Press.

Smith, P.K., Salmivalli, C. \& Cowie, H. (2012). Effectiveness of school-based programs to reduce bullying: A commentary. Journal of Experimental Criminology, 8, 433-441.

Smith, P.K. \& Shu, S. (2000).What good schools can do about bullying: findings from a survey in English schools after a decade of research and action. Childhood, 7(2), 193212. Doi: $10.1177 / 0907568200007002005$

Smith, P.K., \& Watson, D. (2004). Evaluation of the CHIPS (Childline in Partnership with Schools) program. Research report RR570. Nottingham: DfES publications.

Spiel, C, Salmivalli, C. \& Smith, P.K. (2011). Transnational research: National strategies for violence prevention in school. International Journal of Behavioral Development, 35, 381-382. Doi: 10.1177/0165025411407556

Svensson, R. (2003). Tackling violence in schools. A report from Sweden. In P.K. Smith. (Ed.), Violence in schools. The response in Europe. London: RoutledgeFalmer.

Thompson, F. \& Smith, P.K. (2013). Estrategias antibullying dentro de los centros: lo que se hace y lo que funciona. [Anti-bullying strategies in the schools: what's being done and what is working.] In A. Ovejero, P.K. Smith \& Yubero, S. (Coords.) El acoso escolar y su prevención. Perspectivas internacionales (pp.241-262). Madrid: Biblioteca Nueva.

Ttofi, M. \& Farrington, D.P. (2011). Effectiveness of school-based programs to reduce bullying: a systematic and meta-analytic review. Journal of Experimental Criminology, 7, 27-56. Doi: 10.1007/s11292-010-9109-1

Tudge, J. \& Rogoff, B. (1995). Influencias entre iguales en el desarrollo cognitivo: perspectivas piagetiana y vygotskiana. [Peer influence in cognitive development: Piagetian and Vygotskian perspectives.] In P. Fernández Berrocal \& M.A. Melero Zabalza, J. (Eds.), La interacción social en contextos educativos. Madrid: Siglo XXI.

Vygotsky, L.S. (1978). Mind in society. The development of higher psychological processes. Cambridge, Mass.: Cambridge University Press. 